\title{
SHALLOW MARINE TRACE-FOSSILS FROM THE MIDDLE MIOCENE OF THE TEBESSA BASIN (NE ALGERIA) AND THEIR PALEOENVIRONMENTAL IMPLICATIONS
}

\author{
ABDELHAKIM BENKHEDDA 『, NABIL DEFAFLIA (1) \\ Laboratory of Sedimentary Environment, Mineral and Hydric resources of Eastern \\ Algeria, Department of Geology, University of Larbi Tebessi, Algeria. \\ abdelhakim.benkhedda@univ-tebessa.dz (corresponding author),defaflianabil@yahoo.fr
}

AMINE CHERIF (D), MOHAMMED NADIR NAIMI (D)

Laboratory of Geology of Sahara, Department of Sciences of the Earth and The Universe, University of Ouargla, Algeria. acherif11@gmail.com,mohammednadirnaimi@gmail.com

EL-HADI MAZOUZ (D)

University of Larbi-Ben-M'Hidi, 04000, Oum El Bouaghi, Algeria.

emazouz@yahoo.fr

ARTURO PALMA-RAMÍREZ (10

Doctorado en Ciencias en Biodiversidad y Conservación, Área Académica de Biología. Universidad Autónoma del Estado de Hidalgo, Ciudad del Conocimiento, Carretera Pachuca-Tulancingo km 4.5, 42184, Pachuca, Hidalgo, Mexico.

arctoduspr@gmail.com

\begin{abstract}
The northeastern part of Algeria is characterized by Meso-Cenozoic fossiliferous deposits. All the previous studies have been focused on invertebrate and vertebrate body fossils from this region. In the present paper we provide the first ichnological study from the region of Ouenza, Tebessa Wilaya (northeastern Algeria). An ichnoassemblage composed of eight ichnotaxa, namely cf. Archaeonassa isp., Arenicolites isp., Diplocraterion isp., Helminthopsis isp., Palaeophycus tubularis, Skolithos cf. linearis, cf. Taenidium isp., and Thalassinoides isp., reported from the lower Langhian (Middle Miocene) of Aïn Sidi Salah locality (Tebessa Basin) is discussed. These trace-fossils belong to the Skolithos and proximal Cruziana ichnofacies indicating deposition within a shallow marine (littoral). The large size of Thalassinoides suggests well oxygenated setting, under moderate- to high-energy conditions, with occasional storm events.
\end{abstract}

Keywords: trace-fossils, paleoenvironments, shallow marine, Middle Miocene, Tebessa.

RESUMO - A parte nordeste da Argélia é caracterizada por depósitos fossilíferos do Meso-Cenozoico. Todos os estudos anteriores foram focados em fósseis corporais de invertebrados e vertebrados desta região. Neste artigo, apresentamos o primeiro estudo icnológico da região de Ouenza, Tebessa Wilaya (nordeste da Argélia). Discute-se aqui a associação de icnofósseis composta por oito icnotáxons, identificados como cf. Archaeonassa isp., Arenicolites isp., Diplocraterion isp., Helminthopsis isp., Palaeophycus tubularis, Skolithos cf. linearis, cf. Taenidium isp. e Thalassinoides isp., reportados para o Langiano inferior (Mioceno Médio) na localidade de Aïn Sidi Salah (Bacia de Tebessa). Os icnofósseis representam a Icnofácies Skolithos e Cruziana proximal, indicando uma deposição em um contexto marinho raso (litoral). O expressivo tamanho de Thalassinoides sugere um cenário bem oxigenado e condições de alta energia, com eventos ocasionais de tempestades.

Palavras-chave: icnofósseis, paleoambientes, mar raso, Mioceno Médio, Tebessa. 


\section{INTRODUCTION}

In the west Mediterranean Miocene marginal basins, thick marine mixed siliciclastic-carbonate sediments, characterized by abundant ichnofauna, have been deposited (Naimi et al., 2020a). During the last decade, these deposits have been the subject of several ichnological studies particularly in Spain and Italy (Uchman \& Hanken, 2013; Monaco \& Trecci, 2014; Belaústegui et al., 2016). In a shallow marine settings, they contain diverse and spectacular trace-fossil assemblages. However, both bioturbation and bioerosion patterns were sparsely recorded (Doyle et al., 1998; de Gibert \& Robles, 2005).

During the Miocene, several basins have been individualized in the northern part of Algeria, as well as the lower Chelif (Benzina et al., 2019; Naimi, 2019; Naimi et al., 2020a,b; Naimi \& Cherif, 2021), Tafna (Naimi et al., 2021a), Tiaret (Cherif et al., 2021a; Naimi et al., 2021b), and Tebessa basins (Benkhedda et al., 2021). In the lower Chelif, the Tafna and Tiaret Neogene basins, several studies identified Burdigalian to Messinian shallow- to deep-marine trace-fossil assemblages (Naimi et al., 2020a. 2021a,b; Cherif et al., 2021a; Naimi \& Cherif, 2021). Unfortunately, ichnological studies have not been carried out on the Tebessa Basin.

This paper aims to present the first description of lower Langhian trace-fossils from the Ouenza area (Tébessa, eastern Algeria) in the Tebessa Basin.

\section{LOCATION AND GEOLOGICAL BACKGROUND}

The study area belongs to Tebessa Mounts, which constitute the easternmost part of the Algerian Atlasic domain, consisting of the southern part of the Algerian alpine chain (Durand-Delga, 1969; Halamski \& Cherif, 2017).

Tebessa Mounts are characterized by Triassic strata, cropping out as diapirs and composed of gypsum, clays, anhydrite and dolomite (Dubourdieu, 1956). The overlying Cretaceous deposits are characterized by shallow to deep marine limestones and marls. Their infill mainly consists of the mid-Cretaceous deposits (upper Albian-Turonian), where two anoxic events were identified at the end of the Albian (OAE-1d) and the Cenomanian (OAE-2) (Ruault-Djerrab et al., 2014).

The Paleocene-Eocene sediments are characterized by marls, shelly and chalky limestones rich in shark teeth and nummulites, showing phosphorite layers and silex nodules (Kechiched et al., 2016). These phosphorites are rich in glauconite, which may indicate reworking processes of phosphatic particles before their deposition and final burial in a sub-oxic to sub-reduced environment (Kechiched et al., 2018). Furthermore, the Eocene (Coiffait et al., 1984) and Miocene (Mahboubi et al., 2003; Lihoreau et al., 2015) continental deposits of Bir El Ater area, located in the southern margin of the Tebessa Basin, yielded vertebrate remains belonging to proboscideans, hyracoids, rodents, primates, creodonts, insectivores, and artiodactyls. Several new species were also described in this locality. The marine Lower Miocene series is characterized by shallow marine or deltaic sediments that unconformably overlie the Cretaceous strata (Hamimed \& Kowalski, 2001). During the Middle-Late Miocene, the marginal part of this basin was characterized by shallow marine siliciclastic sedimentation (Benkhedda et al., 2021).

The studied outcrop is located at Aïn Sidi Salah locality, to the east of Ouenza city, in the vicinity of the AlgerianTunisian border, in the northern part of the Tebessa Basin (Figure 1). It consists of a succession of yellowish, 2 to $11 \mathrm{~m}$-thick quartz-dominated fine- to coarse-grained sandstones, with sharp erosive bases, showing low-angle cross-stratifications, parallel laminations, ripple marks and bivalve bioclasts intercalated by greyish marls (Figure 2). They contain hematite, goethite, muscovite and glauconitic grains. The sandstone beds are intercalated with greenish to grayish clayey marls, $0.5-39 \mathrm{~m}$ thick, represented essentially by smectite, chlorite, kaolinite and illite clay minerals (Mazouz, 2009). The Table 1 summarizes the main facies (F1-F5) with their principal lithological, sedimentological and ichnological features. This succession is underlined by Triassic claystones and gypsum, and overlain by Laghian-Serravalian conglomerates, which have been assigned previously to the Burdigalian (Dubourdieu, 1956) (Figure 3). The planktonic foraminifera identified are dominated by Globigerina dissimilis Cushman \& Bermúdez, 1937; Globigerinoides trilobus (Reuss, 1850); Globorotalia mayeri Cushman \& Ellisor, 1939; Gyroidinoides girardanus (Reuss, 1851) and Planulina renzi Cushman \& Stainforth, 1945, indicating the early Langhian age.

\section{MATERIAL AND METHODS}

The analyzed material comes from a unique stratigraphic section, measured, and sampled at Aïn Sidi Salah locality, Tebessa Basin. The trace-fossil samples were studied and photographed during the bed-by-bed descriptive observation of the lithological and paleontological aspects of the exposed sequence, as well as their stratigraphic relationships pending on the specificities of the study area. The material was not collected. All photos correspond to field specimens that were not collected and were photographed in situ.

\section{SYSTEMATIC ICHNOLOGY}

The trace-fossil assemblage is poorly diversified, composed of eight ichnotaxa, most of them identified at the ichnogenus level. This study reveals that Skolithos cf. linearis are abundant, Diplocraterion isp., and Thalassinoides isp. are common, whereas cf. Archaeonassa isp., Arenicolites isp., Helminthopsis isp., Palaeophycus tubularis and cf. Taenidium isp. are rare. In addition, most of specimens are preserved as epichnia and endichnia (Table 2). 


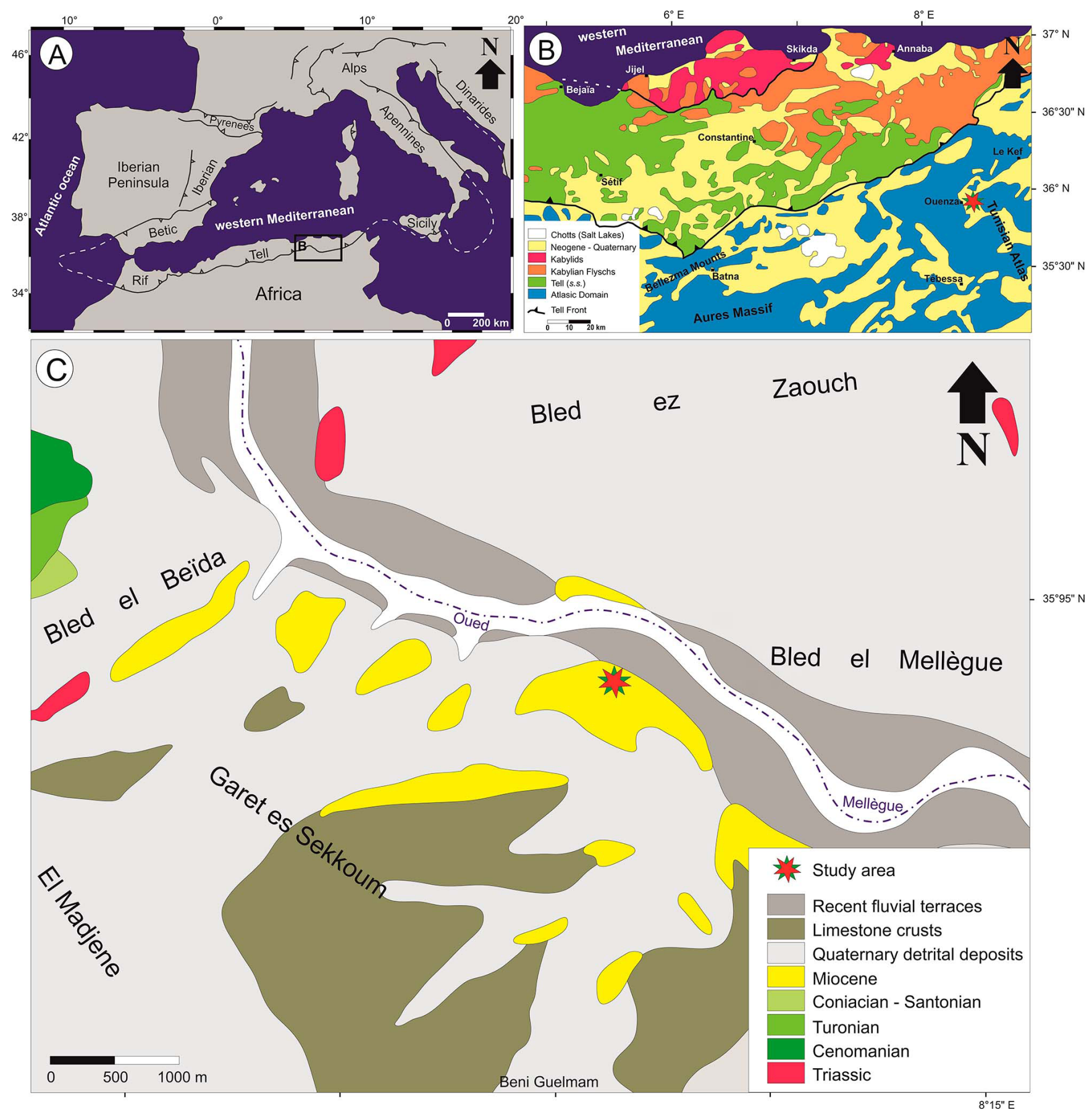

Figure 1. Location of the study area: A, location of northeastern Algeria in the western Mediterranean region and $\mathbf{B}$, geological map of eastern Algeria; $\mathbf{C}$, geological map of Aïn Sidi Salah locality.

\section{Archaeonassa Fenton \& Fenton, 1937}

\section{cf. Archaeonassa isp.}

(Figure 4A)

Description. Subhorizontal, unbranched, cylindrical and rarely meandering trail, preserved as convex hyporelief, composed of concave central zone bounded by two convex parallel lateral ridges. It is found in the top of fine-grained sandstone with ripple marks. No evident ornamentation is seen inside the trail. The trails are $94 \mathrm{~mm}$ length in average, axial groove is $0.5-1 \mathrm{~mm}$ wide and the trail width is 3 to $5 \mathrm{~mm}$.

Remarks. Archaeonassa is a molluscan-type trail (Netto et al., 2012) ranging from the Ediacaran to the Recent (Buckman, 1994). It is considered as a crawling trail of predatory gastropods (Fenton \& Fenton, 1937; Buckman, 1994; Stanley \& Feldmann, 1998), crustaceans (Yochelson \& Fedonkin, 1997; Mángano \& Buatois, 2003), trilobites or echinoids (Buckman, 1994). Yuanyuan et al. (2019) also suggested nereidid polychaetes as probable trace makers. This 


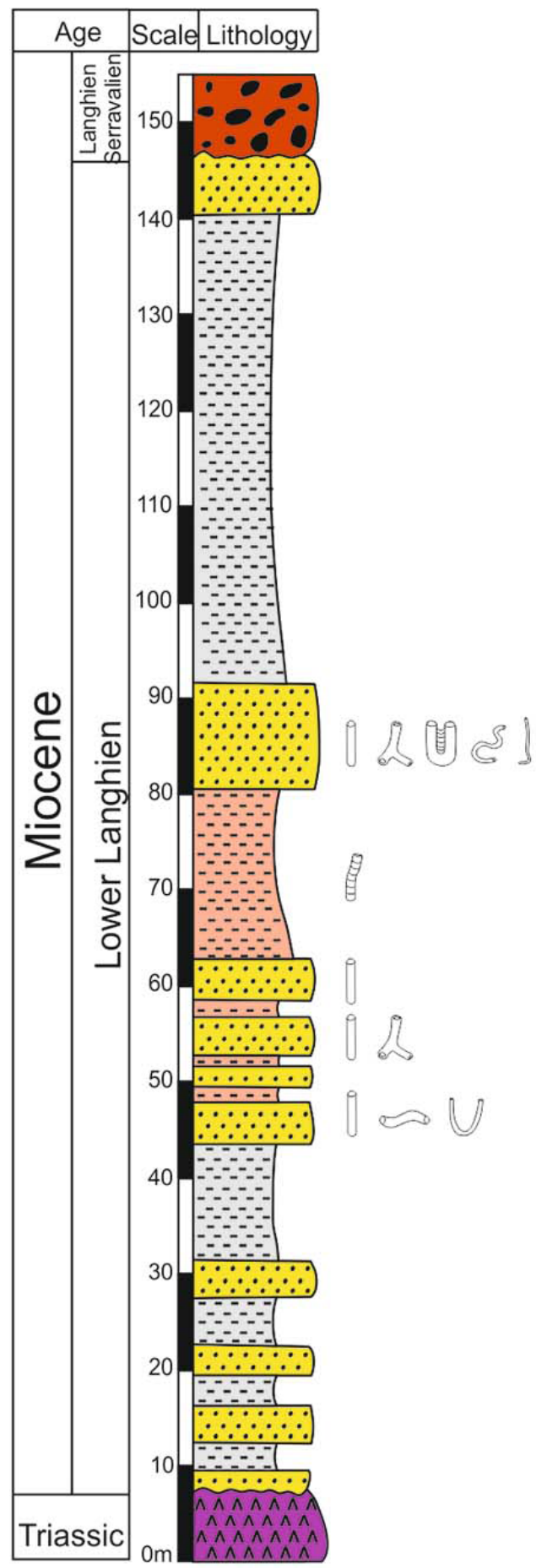

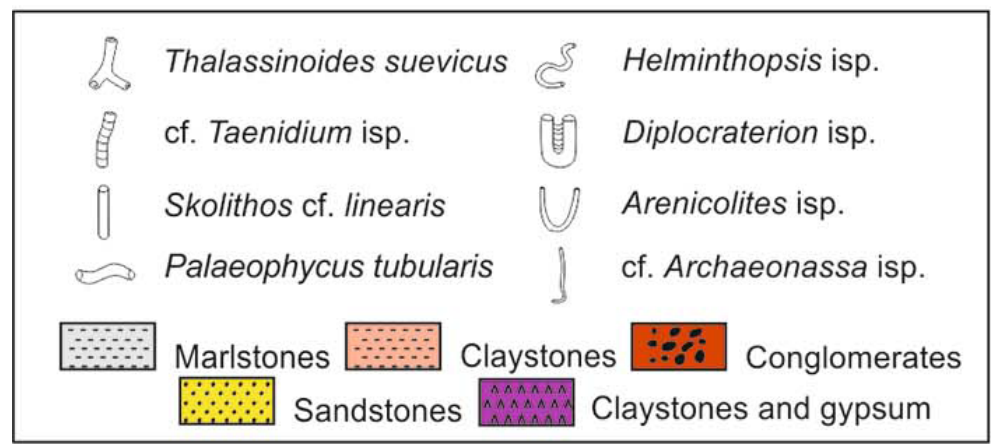

Figure 2. Stratigraphic column and trace-fossils distribution of the Aïn Sidi Salah section (Tébessa, northeastern Algeria). 
Table 1. Distribution of the main facies, ichnogenera and depositional settings.

\begin{tabular}{|c|c|c|c|c|c|}
\hline Facies & General description & Trace-fossils & Sedimentary structures & Sedimentary processes & Environment \\
\hline $\begin{array}{l}\text { Facies F1: } \\
\text { Marlstones }\end{array}$ & $\begin{array}{l}2.5-8.3 \mathrm{~m} \text { thick, massive, grey to } \\
\text { green in color, containing benthic } \\
\text { foraminifera and ostracods, with } \\
\text { intercalations Sandstone beds ( } 0.15 \\
\text { m mean) }\end{array}$ & l & l & $\begin{array}{l}\text { Decantation processes } \\
\text { mainly post-storm or } \\
\text { tide current }\end{array}$ & $\begin{array}{l}\text { Storm-dominated } \\
\text { siliciclastic } \\
\text { platform }\end{array}$ \\
\hline $\begin{array}{l}\text { Facies F2: } \\
\text { Claystones }\end{array}$ & $\begin{array}{l}0.8-5.5 \mathrm{~m} \text { thick, massive, reddish } \\
\text { sandy claystones, intercalated by thin } \\
\text { sandstone levels }\end{array}$ & cf. Taenidium isp. & / & $\begin{array}{l}\text { Decantation processes } \\
\text { and possibly related to } \\
\text { pedogenic processes }\end{array}$ & \\
\hline $\begin{array}{l}\text { Facies F3: } \\
\text { Rippled fine } \\
\text { sandstones }\end{array}$ & $\begin{array}{l}\text { Yellow to grey fine sandstones, } \\
0.6-1.3 \mathrm{~m} \text { thick, intercalated within } \\
\text { marlstone facies, channelized, and } \\
\text { showing ripple marks }\end{array}$ & $\begin{array}{l}\text { cf. Archaeonassa isp. } \\
\text { Diplocraterion isp. } \\
\text { Helminthopsis isp. } \\
\text { Skolithos cf. S. linearis } \\
\text { Thalassinoides isp. }\end{array}$ & $\begin{array}{l}\text { Wavy cross-laminated, } \\
\text { wavy/ripple-marks }\end{array}$ & $\begin{array}{l}\text { Weather wave or tide } \\
\text { current in littoral zone }\end{array}$ & \\
\hline $\begin{array}{l}\text { Facies F4: } \\
\text { Laminated } \\
\text { sandstones }\end{array}$ & $\begin{array}{l}\text { Brown to yellow, fine to medium- } \\
\text { grained, } 0.05-0.4 \mathrm{~m} \text { thick, highly } \\
\text { channelized, with sharp erosive bases }\end{array}$ & $\begin{array}{l}\text { Arenicolites isp. } \\
\text { Palaeophycus tubularis } \\
\text { Skolithos cf. S. linearis }\end{array}$ & $\begin{array}{l}\text { Horizontal and planar } \\
\text { stratification }\end{array}$ & $\begin{array}{l}\text { Deposition under } \\
\text { high and rapid energy } \\
\text { related to storm event }\end{array}$ & \\
\hline $\begin{array}{l}\text { Facies F5: } \\
\text { Storm- } \\
\text { dominated } \\
\text { sandstones }\end{array}$ & $\begin{array}{l}\text { Brown in color, fine to medium } \\
\text { grained sandstone beds, } 0.2-0.45 \mathrm{~m} \\
\text { in thickness, channelized, showing } \\
\text { sometimes calcareous debris }\end{array}$ & $\begin{array}{l}\text { Skolithos cf. S. linearis } \\
\text { Thalassinoides isp. }\end{array}$ & $\begin{array}{l}\text { Hummocky cross- } \\
\text { stratification (HCS), } \\
\text { horizontal lamination }\end{array}$ & $\begin{array}{l}\text { Middle term of the } \\
\text { tempest sequence } \\
\text { from storm-dominated } \\
\text { platform (middle } \\
\text { offshore) }\end{array}$ & \\
\hline
\end{tabular}

Table 2. Main characteristics of the studied ichnoassemblage.

\begin{tabular}{|c|c|c|c|c|}
\hline Ichnotaxa & Toponomy & Abundance & Ethology & Main producers \\
\hline cf. Archaeonassa isp. & Epichnia & Rare & Repichnia, praedichnia & Gastropods, crustaceans \\
\hline Arenicolites isp. & Endichnia & Rare & Domichnia & Worms \\
\hline Diplocraterion isp. & Epichnia & Common & Domichnia & Crustaceans, polychaetes \\
\hline Helminthopsis isp. & Epichnia & Rare & Pascichnia, repichnia & Polychaetes \\
\hline Palaeophycus tubularis & Epichnia & Rare & Domichnia & Worms \\
\hline Skolithos cf. S. linearis & Endichnia & Abundant & Domichnia & Worms, crustaceans \\
\hline cf. Taenidium isp. & Endichnia & Rare & Pascichnia & Arthropods \\
\hline Thalassinoides isp. & Endichnia & Common & Domichnia & Decapod crustaceans \\
\hline
\end{tabular}

trace-fossil is common in the Cruziana ichnofacies (Knaust et al., 2012) but it is also an accessory component of the Skolithos ichnofacies (Melchor et al., 2012). Mesozoic forms occur generally in intertidal zones (Knox \& Miller, 1985; Bryant \& Pickerill, 1990; Buckman, 1992a,b; Chen et al., 2013), offshore environments (Cherif et al., 2018) and deep marine settings (Mángano \& Buatois, 2016).

\section{Arenicolites Salter, 1857 \\ Arenicolites isp.}

(Figure 4B)

Description. Incomplete unbranched U-shaped burrows, at least $125 \mathrm{~mm}$ long, having a pair of closely spaced circles with subvertical orientation, and preserved as endichnia. Tube diameter is $3-6 \mathrm{~mm}$. The distance between the two tube parts is up from $15 \mathrm{~mm}$ to $45 \mathrm{~mm}$. The burrow shows no spreiten. It is filled with brown-grayish fine material.
Remarks. The studied specimen closely resembles the trace-fossil Ancorichnus described from the Carboniferous of the Carnic Alps (Baucon \& De Carvalho, 2008; Figure 4). Arenicolites is interpreted as resulting from the dwelling activity (domichnia) of suspension-feeding organisms (Wilson, 1971; Knaust, 2017), which correspond to holothurians, sipunculans and echiurans (Smilek \& Hembree, 2012; Baucon \& Felletti, 2013; Baucon et al., 2014). In modern marine settings, incipient Arenicolites burrows have been referred to polychaete worms and amphipod crustaceans (Gingras et al., 2008; Bradshaw, 2010; Baucon et al., 2014). Arenicolites burrows are known from continental to deepmarine environments, commonly occurring in deposits of high-energy (Mángano \& Buatois, 2016; Knaust, 2017). This trace-fossil constitutes with Skolithos, Ophiomorpha and Diplocraterion, the most common ichnogenera of the Skolithos ichnofacies, but can also occurs locally in the Cruziana ichnofacies (Knaust, 2017). Its stratigraphic 

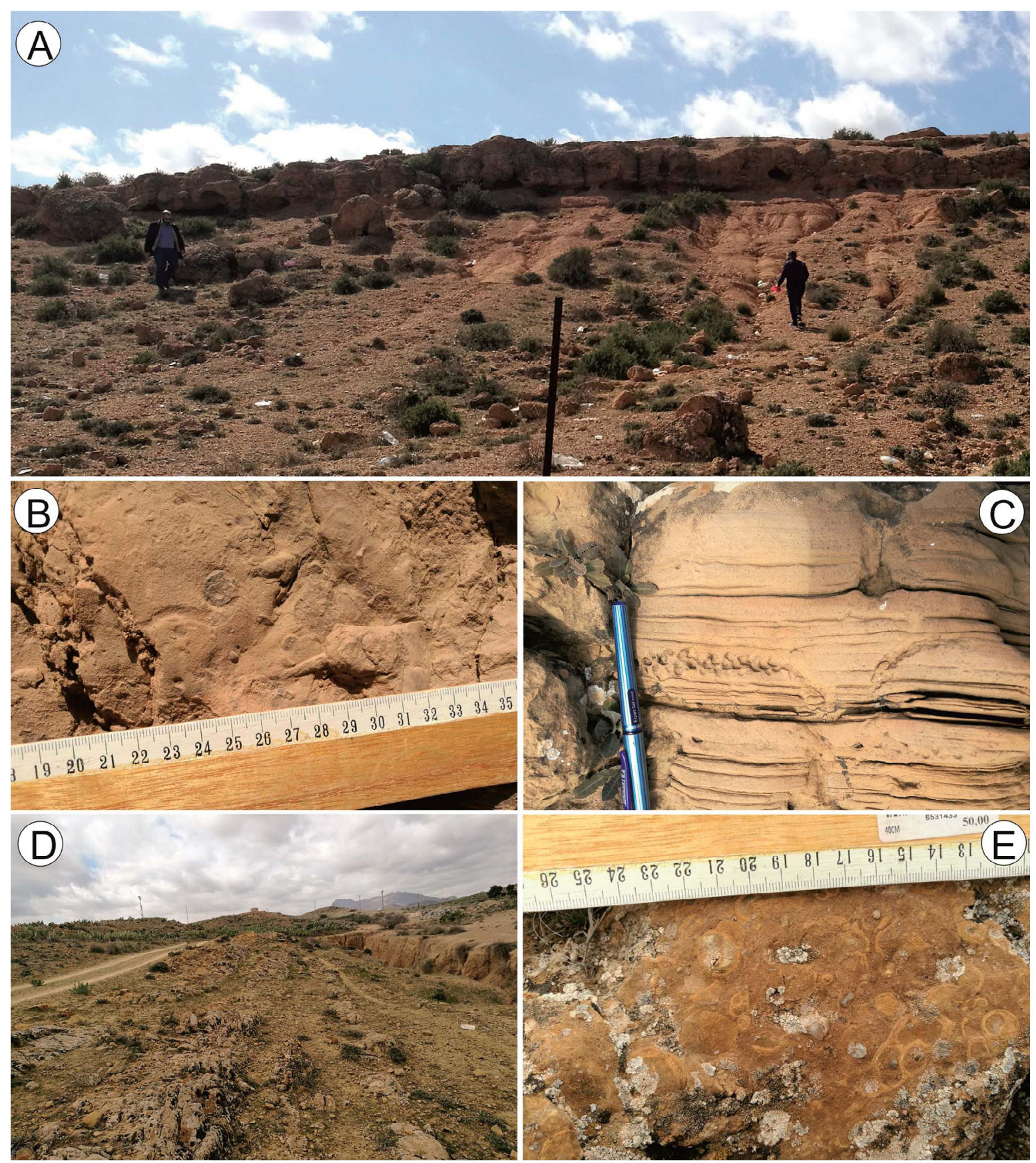

Figure 3. Sedimentary features of the Middle Miocene succession of the Aïn Sidi Salah section: A, field photograph of the upper part of Aïn Sidi Salah section; B, massive bioturbated sandstone; $\mathbf{C}$, laminated sandstone; $\mathbf{D}$, alternances of greyish to greenish marls with sandstone beds; $\mathbf{E}$, massive sandstone showing numerous bioclasts.

distribution ranges from the Cambrian (Crimes et al., 1977) to the Recent (Baucon \& Felletti, 2013).

Diplocraterion Torell, 1870

\section{Diplocraterion isp.}

(Figures 4C, D)

Description. U-shaped, vertical burrow, preserved as epichnia at the top of fine-grained sandstone beds, and no specific characteristics are shown. The burrow diameter varies from 1.5 to $6 \mathrm{~mm}$ and the distance between the two limbs of the U-shaped burrow is $12-13 \mathrm{~mm}$. Due to the plan view; the studied specimens closely resemble the U-shaped trace-fossils Arenicolites and Tisoa. The studied burrows were attributed to Diplocraterion isp. due to the presence of twin funnel-shaped craters characterizing their openings.

Remarks. This domichnion trace is produced in carbonate and siliciclastic settings, within soft- and firmgrounds, by polychaetes and crustaceans (Knaust, 2017). It is characterized 


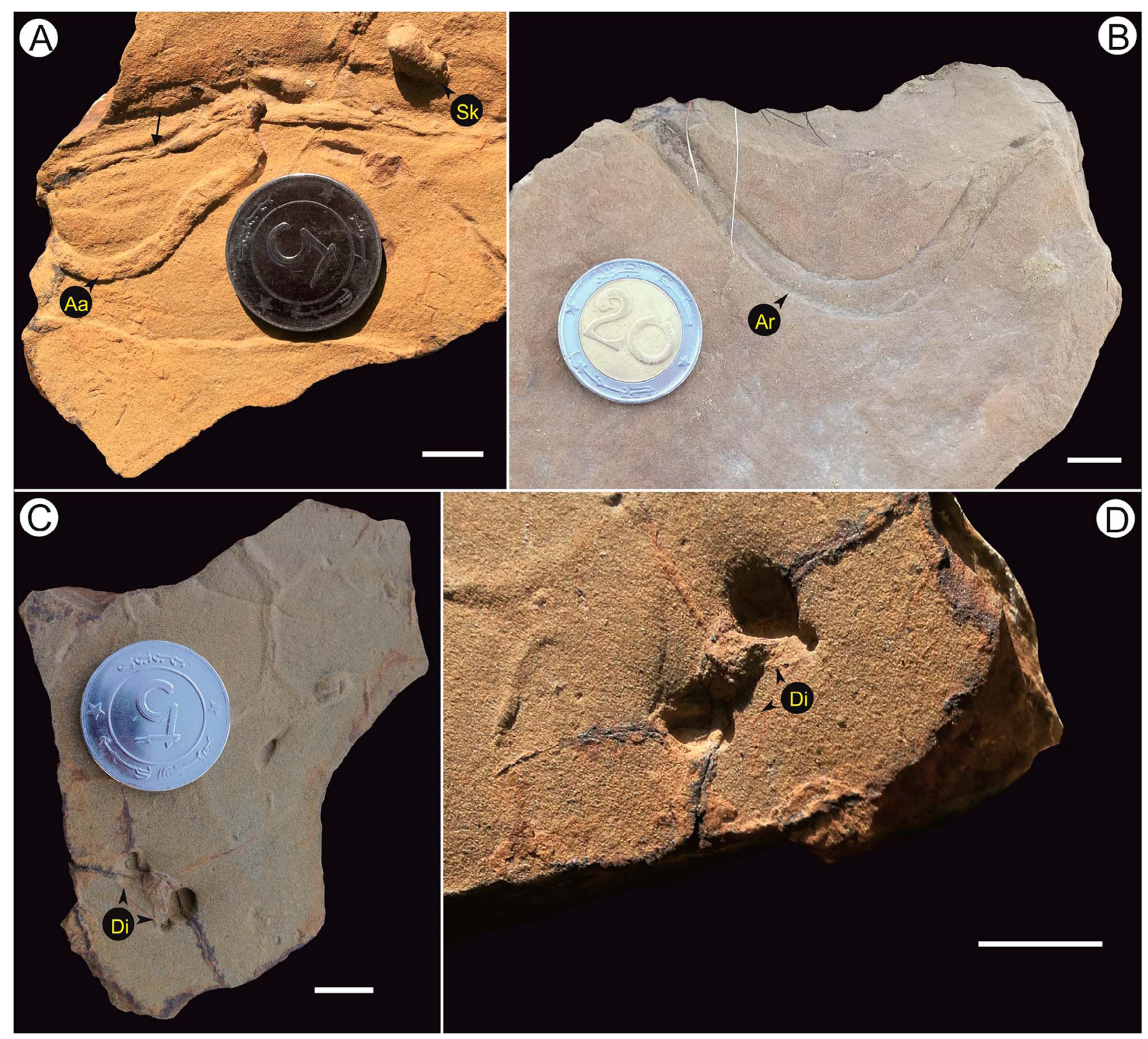

Figure 4. Trace-fossils from the lower Langhian of Aïn Sidi Salah with: A, cf. Archaeonassa isp. (Aa) associated with Diplocraterion isp. (Di) and Skolithos cf. linearis (Sk), black arrow indicates the axial groove of cf. Archaeonassa isp.; B, Arenicolites isp. (Ar) (vertical view); C, D, Diplocraterion isp. (Di). Scale bars $=1 \mathrm{~cm}$.

by a spreite which can be retrusive or protrusive, or both (Goldring, 1962, 1964) and fecal pellets can be also present (Knaust, 2017). Diplocraterion isp., known from Cambrian to the Recent (Mángano \& Buatois, 2016), is generally documented in shallow marine settings (Knaust, 2017; PalmaRamírez et al., 2019) and constitutes an important component of the Skolithos ichnofacies (Knaust, 2017).

\section{Helminthopsis Heer, 1877}

\section{Helminthopsis isp.}

(Figure 5A)

Description. Horizontal simple, smooth, and meandering string, $3 \mathrm{~mm}$ in diameter and $160 \mathrm{~mm}$ in length, preserved as a concave epichnial ridge in fine-grained sandstone.
Remarks. Helminthopsis is a pre-depositional graphoglyptid ichnotaxon, occurring within a sediment rich in nutrients of shallow and deep marine deposits (Uchman, 1995, 1998; Wetzel \& Bromley, 1996; Wetzel et al., 2007; Cherif et al., 2021a). It is commonly interpreted as a pascichnion trace-fossil (Buatois \& Mángano, 2011), probably made by grazing activity of polychaete annelids (Książkiewicz, 1977). In shallow marine setting, Helminthopsis ichnospecies are common in the Cruziana ichnofacies (MacEachern et al., 2007; Belaid et al., 2020). They have been recorded from Ediacaran (Narbonne \& Aitken, 1990) to Recent strata (Gingras et al., 2008) deposited below storm wave base.

\section{Palaeophycus Hall, 1847}

\section{Palaeophycus tubularis Hall, 1847}

(Figure 5B) 
Description. Epichnial convex, simple, straight, unbranched, cylindrical to subcylindrical burrow, horizontal to bedding. Diameter is $15 \mathrm{~mm}$, and the maximum length is $104 \mathrm{~mm}$. The burrow lacks ornamentation and is filled with identical material to that of the host rock.

Remarks. The studied burrow has been assigned to Palaeophycus tubularis due to the presence of unornamented walls (Pemberton \& Frey, 1982). It occurs in soft- to firmgrounds of both siliciclastic and carbonate deposits (Knaust, 2017). Palaeophycus ichnospecies reflect the dwelling activity (domichnion) of a predaceous or suspensionfeeding animal (Pemberton \& Frey, 1982). However, its tracemakers consist of vermiform animals, so other groups of organisms such as arthropods may produce it (Knaust, 2017). Modern Palaeophycus are produced by nereidid polychaetes (Dashtgard \& Gingras, 2012; Gingras et al., 2012), and the co-occurrences with large burrows, in marginal-littoral environments indicate that the tracemaker was euryhaline (Knaust, 2017). Palaeophycus is common in shoreface and offshore deposits of the Cruziana ichnofacies, and occurs subordinately in the Skolithos, Zoophycos and Nereites ichnofacies (Knaust, 2017). Palaeophycus has been reported from the Precambrian (Narbonne \& Hofmann, 1987) to the Pleistocene (Dashtgard \& Gingras, 2012; Gingras et al., 2012).

Skolithos Haldeman, 1840

\section{Skolithos cf. linearis Haldeman, 1840} (Figures 4A, 5A, C)

Description. Preserved as endichnia straight, simple, elongated, vertical to subvertical, cylindrical and unbranching tube, with lined walls and passive filling. The burrows are 55 $\mathrm{mm}$ long on average and 5-12 $\mathrm{mm}$ wide.

Remarks. In siliciclastic setting, Skolithos ichnospecies occur in soft- to firmgrounds (Knaust, 2017). They are domichnial (dwelling) traces, produced by suspension-feeding worms (Fenton \& Fenton, 1934; Emig, 1982; Sundberg, 1983; Dashtgard \& Gingras, 2012; Vinn \& Wilson, 2013), crustaceans (Dashtgard \& Gingras, 2012) and sea anemones in marine setting (Hertweck, 1972). Skolithos is the namesake for the Skolithos ichnofacies, commonly used as indicator of high energy conditions of shallow marine (littoral) environments (Knaust, 2017). Its stratigraphic record ranges from the Cambrian to the recent (Mángano \& Buatois, 2016).

\section{Taenidium Heer, 1877}

\section{cf. Taenidium isp.}

(Figure 5D)

Description. cf. Taenidium isp. is winding, unbranched, and thinly lined burrow, vertical to the bedding plane, preserved as endichnial in sandy-claystone facies, up to $100 \mathrm{~mm}$ long and about $5 \mathrm{~mm}$ in diameter. The single specimen is moderately preserved, but in some segments, it is possible to see active meniscate-shaped filling.
Remarks. Taenidium is regarded as deposit-feeding, locomotion, and dwelling trace-fossil (Hembree \& Hasiotis, 2008 ), produced probably by arthropods (Rodríguez-Tovar $e t$ al., 2016). It is recorded in shallow to deep-marine deposits (D'Alessandro et al., 1987), considered as characteristic element of the Scoyenia ichnofacies (Buatois \& Mángano, 2011; Melchor et al., 2012). ichnospecies of Taenidium occur also in the Cruziana ichnofacies (Bromley et al., 1999; Cherif et al., 2018). This trace-fossil is known from the Cambrian to the recent (Mángano \& Buatois, 2016).

\section{Thalassinoides Ehrenberg, 1944 \\ Thalassinoides isp. (Figure 5E)}

Description. Straight or slightly curved, oblique, large, mostly with $\mathrm{Y}$ - to T-shaped branched burrowing network, $10-30 \mathrm{~mm}$ wide and 50 to $150 \mathrm{~mm}$ long. Thalassinoides isp. has been found in endichnia in the internal face of the stormdominated sandstones (Facies F5).

Remarks. Thalassinoides is considered as fodinichniondomichnion trace of decapod crustaceans (Frey et al., 1984). It represents the main component of the Cruziana ichnofacies (Knaust, 2017) and is often documented from shallow marine to deep-sea environments (Kim et al., 2002; Cherif et al., 2021b), supporting high energy conditions (Cherif et al., 2015), and occurring in soft- to firmgrounds, but rarely in hardgrounds (Knaust, 2017). In shallow marine setting, the abundance and the developed size of Thalassinoides suggest well-oxygenated deposits (Naimi et al., 2020a; Naimi \& Cherif, 2021). This trace-fossil is frequently reported from the Ordovician (Ekdale \& Bromley, 2003) to the Holocene (Nickell \& Atkinson, 1995), especially in the Mesozoic and Cenozoic deposits (El-Sabbagh et al., 2017).

\section{DISCUSSION}

\section{Ichnological analysis}

The trace-fossils were recorded from claystones, rippled fine sandstones, laminated sandstones and storm-dominated sandstones which show densely packed bioclast-supported shell layers. The trace-fossil assemblage is characterized by sub-horizontally to sub-vertically burrows belonging to cf. Archaeonassa isp., Arenicolites isp., Diplocraterion isp., Helminthopsis isp., Palaeophycus tubularis, Skolithos cf. S. linearis, cf. Taenidium isp., and Thalassinoides isp. The most abundant trace-fossil is $S$. cf. linearis. The low ichnodiversity observed could be the result of stress factors such as high energy (Buatois \& Mángano, 2013).

The ichnoassemblage in subject is dominated by post-depositional dwelling (domichnia) traces attributed essentially to suspension- or deposit-feeding organisms (e.g. Thalassinoides isp.). Shallow marine trace-fossils show more ethological variations than that of other environments (Joseph et al., 2020), which is the main characteristic of the 

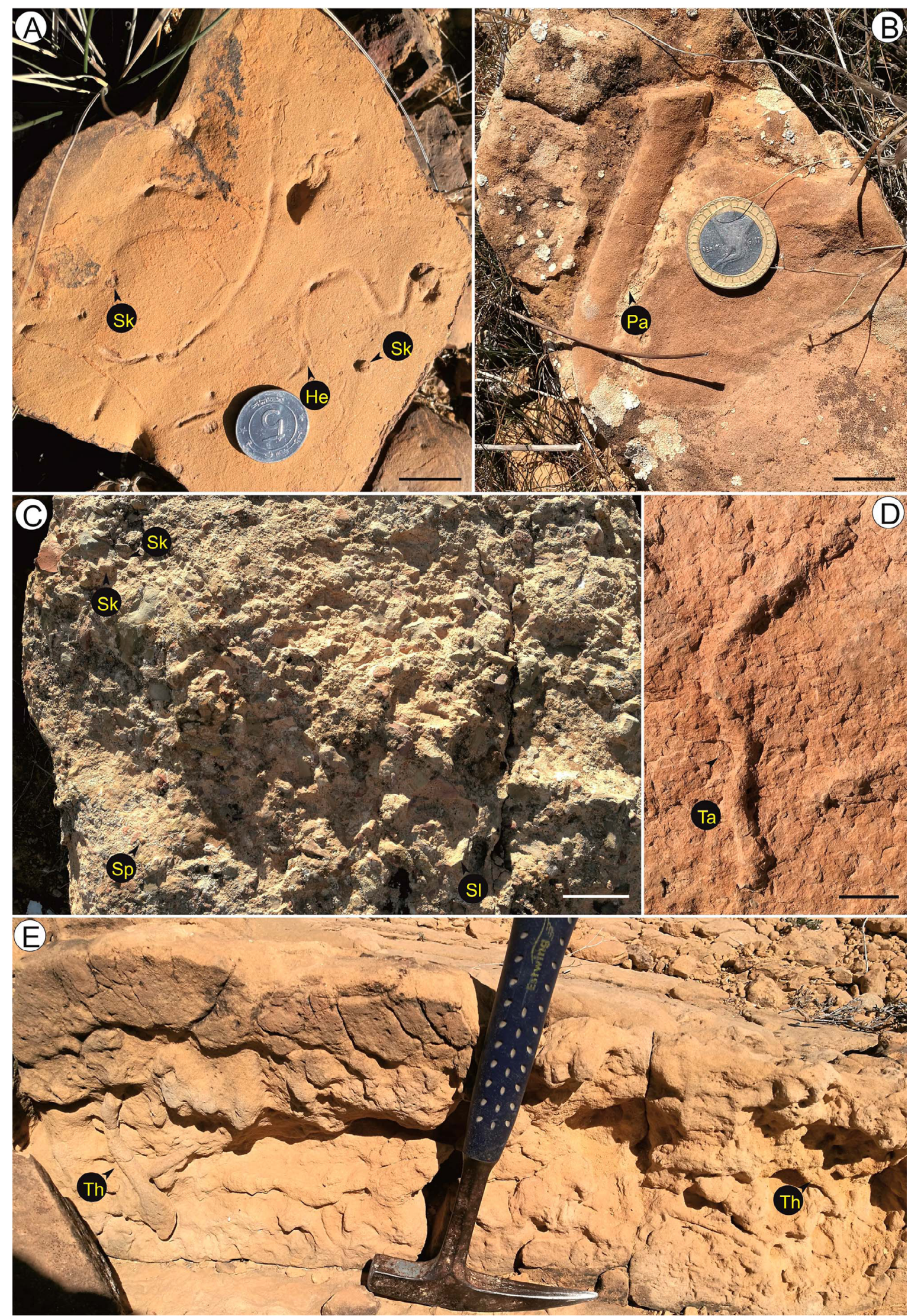

Figure 5. Trace-fossils from the lower Langhian of Aïn Sidi Salah: A, Helminthopsis isp. (He) associated with Skolithos cf. S. linearis (Sk); B, Palaeophycus tubularis (Pa); C, sandstone bed rich in Skolithos cf. S. linearis burrows (Sk), with probably pipe structures of S. cf. S. linearis burrows (Sp), and its lost traces (SI) ; D, cf. Taenidium isp. (Ta) (the possible meniscate fill is indicated by white arrow); E, sandstone bed showing abundant Thalassinoides suevicus (Th). Scale bars: $A-B=2 \mathrm{~cm} ; C=5 \mathrm{~cm} ; \mathrm{D}=1 \mathrm{~cm}$. 
proximal and archetypical Cruziana ichnofacies, within an upper offshore-lower shoreface environment (Pemberton et al., 2001). Mazouz (2009) suggested for the Tebessa Basin a shallow marine environment under moderate to high energy conditions based on a sedimentological approach. Thereby, the occurrence of vertical structures indicates opportunistic colonization of the storm-dominated sandstones (post-event community); whereas the presence of horizontal structures (laminated sandstones) is related to fair weather conditions (Pervesler \& Uchman, 2004). The preservation of the post-depositional trace-fossil Arenicolites and Skolithos in the sandstone beds could indicate a storm-related highenergy environment of the lower to middle shoreface (MacEachern et al., 2012). Furthermore, the debris of bivalve shells could be related to storm events (tempestitedeposits) and suggest a shoreface depositional environment. Thalassinoides characterizes softgrounds (Myrow, 1995) and its co-occurrence with large and open burrows, as well as Palaeophycus, indicates a shallow marine environment with well-oxygenated water above the sea floor (Naimi et al., 2020a; Naimi \& Cherif, 2021). The worms (polychaetes and phoronids) are the most common producers of the studied trace-fossils, but crustaceans and arthropods are also probable tracemakers of these structures. The studied ichnoassemblage together with the paleontological data as well as the recorded bivalves are suggestive of adequate food resources both in substrate and water column under normal salinity conditions (Fürsich, 1973; Wilson \& Rigby, 2000; Mángano et al., 1999; 2005; Gurav et al., 2014)

Water with relatively strong currents, irregular rates of sedimentation and a high flux of food particles is conducive to the occurrence of suspension feeders (Buatois \& Mángano, 2011). Gingras et al. (2011) also regarded the abundance of permanent U-shaped burrows and vertical tubes as indicative of shallow-marine areas with shifting sandy substrates, moderate-to high-energy conditions and food in suspension. From an ichnological point of view, the sequence shows a shift in environmental conditions, from the nearshore to the offshore zone. The colonization occurred in fully oxygenated shallow-marine waters, in a high-energy setting.

The trace-fossil assemblage of Aïn Sidi Salah is intimately related to shallow marine ichnofacies and typically shows development of Skolithos, which is the diagnostic of Skolithos ichnofacies type conditions.

\section{Paleogeography}

During the Early-Middle Miocene, a significant marine transgression began across the expanse of epicontinental Algeria (Bessedik et al., 2002). A patch reef indicating the maximum flooding has been discovered in the LanghianSerravalian transgressive detrital strata of the Lower Chelif Basin (Belkebir et al., 1994). This transgression has been recorded from the entire western Mediterranean Basin, as result of the opening of the Algero-Provençal Basin, occupying the western part of the Mediterranean Sea (de Gibert \& Robles, 2005). These transgressive deposits are overlain by continental reddish detrital sediments attributed to the Serravalian
(Bessedik et al., 2002). The Miocene series ends by Late Miocene (Tortonian-Messinian) marine transgressive deposits (Benzina et al., 2019; Naimi et al., 2020a).

The attribution of the studied deposits to the lower Langhian on the basis of planktonic foraminifera allows correlating the Tebessa basin with the other marginal basins of the southwestern Mediterranean as well as the Lower Chelif Basin. The bioturbated sandstones (Facies F3-F5) have been deposited within a transgressive context related to a significant transgression recorded in the other peri-Mediterranean basins. Also, they are overlain by reddish conglomerates which are similar to that of the Lower Chelif Basin, indicating the Middle Miocene regression phase. The latter are surmounted by Upper Miocene marine siliciclastic deposits as well as in the case of the Lower Chelif and the Tafna basins (Benkhedda et al., 2021). Thus, it confirms the similarities between the Tebessa and the Lower Chelif basin, which presents the reference Miocene series of Algeria.

\section{CONCLUSIONS}

Ichnological analysis of the Aïn Sidi Salah lower Langhian sequence revealed low ichnodiversity represented by subhorizontally to sub-vertically oriented burrows belonging to eight ichnotaxa of Skolithos and proximal Cruziana Ichnofacies. Thus, these trace-fossils are cf. Archaeonassa isp., Arenicolites isp., Diplocraterion isp., Helminthopsis isp., Palaeophycus tubularis, Skolithos cf. linearis, cf. Taenidium isp., and Thalassinoides isp. The Skolithos ichnofacies suggests high hydrodynamic energy reflecting foreshoreshoreface environment with occasional storm events, while proximal Cruziana ichnofacies represents moderate energy condition of shoreface. This ichnoassemblage suggests that suspension- or deposit- feeding organisms, represented essentially by worms (polychaetes and phoronids), crustaceans and arthropods, occurred within these deposits, despite the absence of their body fossils.

\section{ACKNOWLEDGMENTS}

This paper is a part of the PhD thesis of Abdelhakim Benkhedda. We thank the associated Editor of Revista Brasileira de Paleontologia, M.N. Ritter, and the three reviewers, H. Francischini, J. Villegas-Martín and D. Sedorko, for the comments on early drafts of this manuscript.

\section{REFERENCES}

Baucon, A. \& De Carvalho, C.N. 2008. From the river to the sea: Pramollo, a new ichnolagerstätte from the Carnic Alps (Carboniferous, Italy-Austria). Studi Trentini di Scienze Naturali, Acta Geologica, 83:87-114.

Baucon, A. \& Felletti, F. 2013. Neoichnology of a barrierisland system: the Mula di Muggia (Grado lagoon, Italy). Palaeogeography, Palaeoclimatology, Palaeoecology, 375:112124. doi:10.1016/j.palaeo.2013.02.011 
Baucon, A; Ronchi, A. \& Felletti F. 2014. Evolution of crustaceans at the edge of the end-Permian crisis: ichnonet work analysis of the fluvial succession of Nurra (Permian-Triassic, Sardinia, Italy). Palaeogeography, Palaeoclimatology, Palaeoecology, 410:74-103. doi:10.1016/j.palaeo.2014.05.034

Belaid, M.; Cherif, A.; Vinn, O. \& Naimi, M.N. 2020. First record of trace-fossils from the Oxfordian Argiles rouges de Kheneg Formation (Tiaret, northwestern Algeria). Geologia Croatica, 73:85-94. doi:10.4154/gc.2020.10

Belaústegui, Z.; Ekdale, A.A.; Domènech, R. \& Martinell, J. 2016. Paleobiology of firmground burrowers and cryptobionts at a Miocene omission surface, Alcoi, SE Spain. Journal of Paleontology, 90:721-733. doi:10.1017/jpa.2016.84

Belkebir, L.; Mansour, B.; Bessedik, M.; Saint Martin, J.P.; Belarbi, M. \& Chaix, C. 1994. Présence d'une construction récifale corallienne à Djebel Chott (Dahra occidental, Algérie): témoin du maximum transgressif du Miocène moyen en Méditerranée. Géologie Méditerranéenne, 21:1-7.

Benkhedda, A.; Defaflia, N.; Cherif, A.; Benzina, M.; Kechiched, R.; Naimi, M.N. \& Djerrab-Ruault, M. 2021. Upper Miocene deposits from El Ma Labiod (Tébessa, Northeastern Algeria): sedimentology, micropaleontology and paleoenvironmental implications. Russian Journal of Earth Sciences, 22:ES1002. doi:10.2205/2021ES000768

Benzina, M.; Hebib, H. \& Bensalah, M. 2019. New insights in late Miocene lower Chelif basin biostratigraphy based on planktonic foraminifera (Algeria). Revue de Micropaléontologie, 62:9-24. doi:10.1016/j.revmic.2018.10.005

Bessedik, M.; Belkebir, L. \& Mansour, B. 2002. Révision de l'âge Miocène inférieur (au sens des anciens auteurs) des dépôts du bassin du Bas Chélif (Oran, Algérie): conséquences biostratigraphiques et géodynamiques. Mémoires $d u$ Service Géologique de l'Algérie, 11:167-186.

Bradshaw, M.A. 2010. Devonian trace-fossils of the Horlick Formation, Ohio Range, Antarctica: systematic description and palaeoenvironmental interpretation. Ichnos, 17:58-114. doi:10.1080/10420941003659329

Bromley, R.G.; Ekdale, A.A. \& Richter, B. 1999. New Taenidium (trace-fossil) in the Upper Cretaceous chalk of northwestern Europe. Bulletin of the Geological Society of Denmark, 46:47-51.

Bryant, I.D. \& Pickerill, R.K. 1990. Lower Cambrian tracefossils from the Buen Formation of central North Greenland: preliminary observations. Grønlands Geologiske Undersøgelse, Rapport, 147:44-62.

Buatois, L.A. \& Mángano, M.G. 2011. Ichnology. Organismsubstrate interactions in space and time. Cambridge, Cambridge University Press, 347 p.

Buatois, L.A. \& Mángano, M.G. 2013. Ichnodiversity and ichnodisparity: significance and caveats. Lethaia, 46:281-292. doi:10.1111/let.12018

Buckman, J.O. 1992a. Palaeoenvironment of a Lower Carboniferous sandstone succession northwest Ireland: ichnological and sedimentological studies. In: J. Parnell (ed.) Basins on the Atlantic Seaboard: Petroleum Sedimentology and Basin Evolution, Geological Society Special Publication, vol. 62, p. 217-241. doi:10.1144/GSL.SP.1992.062.01.19

Buckman, J.O. 1992b. Lower Carboniferous Trace-fossils from northwest Ireland. Queen's University, Ph.D. Thesis, 356 p.

Buckman, J.O. 1994. Archaeonassa Fenton and Fenton 1937 reviewed. Ichnos, 3:185-192. doi:10.1080/10420949409386387

Chen, Z.; Zhou, C.; Meyer, M.; Xiang, K.; Schiffbauer, J.D.; Yuan, X. \& Xiao, S. 2013. Trace-fossil evidence for Ediacaran bilaterian animals with complex behaviors. Precambrian Research, 224:690-701. doi:10.1016/j.precamres.2012.11.004
Cherif, A.; Benyoucef, M.; Ferré, B. \& Benhamou, M. 2018. Etude sédimentologique et ichnologique de la Formation des Argiles de Saïda (Jurassique supérieur) dans les monts de Frenda (Algérie nord-occidentale). Revue de Paléobiologie, 37:121-135. doi:10.5281/zenodo. 1315455

Cherif, A.; Bert, D.; Benhamou, M. \& Benyoucef, M. 2015. La Formation des Argiles de Saïda (Jurassique supérieur) dans le domaine tlemcenien oriental (Takhemaret, Algérie): données biostratigraphiques, ichnologiques et sédimentologiques. Revue de Paléobiologie, 34:363-384. doi:10.5281/zenodo.34344

Cherif, A.; Naimi, M.N. \& Belaid, M. 2021a. Deep-sea trace-fossils and depositional model from the lower Miocene Tiaret Marls Formation (northwestern Algeria). Journal of African Earth Sciences, 175:104115. doi:10.1016/j.jafrearsci.2021.104115

Coiffait, P.E.; Coiffait, B.; Jaeger, J.J. \& Mahboubi, M. 1984. Un nouveau gisement à mammifères fossiles d'âge Eocène supérieur sur le versant sud des Nementcha (Algérie orientale): découverte des plus anciens rongeurs d'Afrique. Comptes Rendus de l'Académie des Sciences, 299:893-898.

Crimes, T.P.; Legg, I. \& Marcos, A. 1977. ?Late Precambrian-low Lower Cambrian trace-fossils from Spain. In: T.P. Crimes \& J.C. Harper (eds.) Trace-fossils 2, Geological Journal, Special Issue, vol. 9, p. 91-138.

D’Alessandro, A.; Bromley, R.G. \& Stemmerik, L. 1987. Rutichnus: a new ichnogenus for branched, walled, meniscate tracefossils. Journal of Paleontology, 61:1112-1119. doi:10.1017/ S0022336000029498

Dashtgard, S.E. \& Gingras, M.K. 2012. Marine invertebrate neoichnology. In: D. Knaust \& R.G. Bromley (eds.) Trace-fossils as indicators of Sedimentary environments, Elsevier, p. 273-295. doi:10.1016/B978-0-444-53813-0.00004-6

de Gibert, J.M. \& Robles, J.M. 2005. Firmground ichnofacies recording high-frequency marine flooding events (Langhian transgression, Vallès-Penedès Basin, Spain). Geologica Acta, 3:295-305. doi:10.1344/105.000001397

Doyle, P.; Bennett, M.R. \& Cocks, F.M. 1998. Borings in a boulder substrate from the Miocene of southern Spain. Ichnos, 5:277286. doi:10.1080/10420949809386426

Dubourdieu, G. 1956. Etude géologique de la région de l'Ouenza (confins algéro-tunisiens). Publications du Service de la Carte Géologique de l'Algérie, 10:1-659.

Durand-Delga, M. 1969. Mise au point sur la structure du Nord-Est de la Berbérie. Publications du Service Géologique de l'Algérie, 39:89-131.

Ekdale, A.A. \& Bromley, R.G. 2003. Paleoethologic interpretation of complex Thalassinoides in shallow-marine limestones, Lower Ordovician, southern Sweden. Palaeogeography, Palaeoclimatology, Palaeoecology, 192:221-227. doi:10.1016/ S0031-0182(02)00686-7

El-Sabbagh, A.; El-Hedeny, M. \& Al Farraj, S. 2017. Thalassinoides in the Middle Miocene succession at Siwa Oasis, northwestern Egypt. Proceedings of the Geologists 'Association, 128:222-233. doi:10.1016/j.pgeola.2017.01.001

Emig, C.C. 1982. The biology of Phoronida. Advances in Marine Biology, 19:1-89.

Fenton, M.A. \& Fenton, C.L. 1934. Scolithus as a fossil phoronid. Pan-American Geologist, 61:341-348.

Fenton, C.L. \& Fenton, M.A. 1937. Archaeonassa, Cambrian snail trails and burrows. American Midland Naturalist, 18:454-456.

Frey, R.W.; Pemberton, S.G. \& Fagerstrom, J.A. 1984. Morphological, ethological, and environmental significance of the ichnogenera Scoyenia and Ancorichnus. Journal of Paleontology, 58:511528. 
Fürsich, F.T. 1973. A revision of the trace-fossils Spongeliomorpha, Ophiomorpha and Thalassinoides. Neues Jahrbuch für Geologie und Paläontologie, 1973:719-735.

Gingras, M.K.; Baniak, G.; Gordon, J.; Hovikoski, J.; Konhauser, K.O.; La Croix, A.; Lemiski, R.; Mendoza, C.; Pemberton, G.S.; Polo, C. \& Zonneveld, J.-P. 2012. Estuaries. In: D. Knaust \& R.G. Bromley (eds.) Trace-fossils as indicators of sedimentary environments, Elsevier, p. 463-505. doi:10.1016/B978-0-44453813-0.00004-6

Gingras, M.K.; Dashtgard, S.E.; MacEachern, J.A. \& Pemberton, S.G. 2008. Biology of shallow marine ichnology: a modern perspective. Aquatic Biology, 2:255-268. doi:10.3354/ab00055

Gingras, M.K.; MacEachern, J.A. \& Dashtgard, S.E. 2011. Process ichnology and the elucidation of physico-chemical stress. Sedimentary Geology, 237:115-134. doi:10.1016/j. sedgeo.2011.02.006

Goldring, R. 1962. The trace-fossils of the Baggy Beds (Upper Devonian) of North Devon, England. Paläontologische Zeitschrift, 36:232-251.

Goldring, R. 1964. Trace-fossils and the sedimentary surface in shallow water marine sediments. Developments in Sedimentology, 1:136-143. doi:10.1016/S0070-4571(08)70478-3

Gurav, S.S.; Kulkarni, K.G.; Paranjape, A.R. \& Borkar, V.D. 2014. Palaeoenvironmental implications of Middle Jurassic tracefossils from the Jaisalmer Formation, India, with emphasis on the ichnogenus Asteriacites. Annales Societatis Geologorum Poloniae, 84:249-257.

Halamski, A.T. \& Cherif, A. 2017. Oxfordian brachiopods from the Saïda and Frenda mountains (Tlemcenian Domain, northwestern Algeria). Annales Societatis Geologorum Poloniae, 87:141-156. doi:10.14241/asgp.2017.006

Hamimed, M. \& Kowalski, W.M. 2001. Sedimentological analysis and paleogeography of the Miocene sediments (LanghianSerravalian) of the surroundings of Tebessa (North-East of Algeria). Bulletin of the Geological Service of Algeria, 12:49-75.

Hembree, D.I. \& Hasiotis, S.T. 2008. Miocene vertebrate and invertebrate burrows defining compound paleosols in the Pawnee Creek Formation, Colorado, U.S.A. Palaeogeography, Palaeoclimatology, Palaeoecology, 270:349-365. doi:10.1016/j. palaeo.2008.07.019

Hertweck, G. 1972. Georgia coastal region, Sapelo Island, U.S.A.: sedimentology and biology V. Distribution and environmental significance of lebensspuren and in-situ skeletal remains. Senckenbergiana Maritima, 4:125-167.

Joseph, J.K.; Patel, S.J.; Darngawn, J.L. \& Shitole, A.D. 2020. Ichnological analysis of Jurassic shallow to marginal marine deposits: example from Wagad Highland, Western India. Ichnos, 27:35-63. doi:10.1080/10420940.2019.1612390

Kechiched, R.; Laouar, R.; Bruguier, O.; Laouar-Salmi, S.; AmeurZaimeche, O. \& Foufou, A. 2016. Preliminary data of REE in Algerian phosphorites: a comparative study and paleo-redox insights. Procedia Engineering, 138:19-29. doi:10.1016/j. proeng.2016.02.048

Kechiched, R.; Laouar, R.; Bruguier, O.; Salmi-Laouar, S.; Kocsis, L.; Bosch, D.; Foufou, A.; Ameur-Zaimeche, O. \& Larit, H. 2018. Glauconite-bearing sedimentary phosphorites from the Tébessa region (eastern Algeria): evidence of REE enrichment and geochemical constraints of their origin. Journal of African Earth Sciences, 145:190-200. doi:10.1016/j.jafrearsci.2018.05.018

Kim, J.Y.; Kim, K.S. \& Pickerill, R.K. 2002. Cretaceous Nonmarine Trace-fossils from the Hasandong and Jinju Formations of the
Namhae Area, Kyongsangnamdo, Southeast Korea. Ichnos, 9:41-60. doi:10.1080/10420940190034076

Knaust, D. 2017. Atlas of trace-fossils in well core: appearance, taxonomy and interpretation. Stavanger, Springer, 209 p.

Knaust, D.; Curran, H.A. \& Dronov, A.V. 2012. Shallow-Marine Carbonates. In: D. Knaust \& R.G. Bromley (eds.) Trace-fossils as Indicators of Sedimentary Environments, Elsevier, p. 705-750. doi:10.1016/B978-0-444-53813-0.00004-6

Knox, L.W. \& Miller, M.E. 1985. Environmental control of tracefossil morphology. In: H.A. Curran (ed.) Biogenic structures: their use in interpreting depositional environments, The Society of Economic Paleontologists and Mineralogists, Special Publications, vol. 35, p. 167-176.

Książkiewicz, M. 1977. Trace-fossils in the Flysch of the Polish Carpathians. Palaeontologia Polonica, 36:1-208.

Lihoreau, F.; Hautier, L. \& Mahboubi, M. 2015. The new Algerian locality of Bir el Ater: validity of Libycosaurus algeriensis (Mammalia, Hippopotamoidea) and the age of the Nementcha Formation. Palaeovertebrata, 39:e1. doi:10.18563/pv.39.2.e1

MacEachern, J.A.; Pemberton, S.G.; Gingras, M.K.; Bann, K.L. 2007. The ichnofacies paradigm: a fifty-year retrospective. In: W. Miller, III (ed.) Trace-fossils: concepts, problems, prospects, Elsevier, p. 52-77.

MacEachern, J.A.; Dashtgard, S.E.; Knaust, D.; Catuneanu, O.; Bann and, K.L. \& Pemberton, S.G. 2012. Sequence stratigraphy. In: D. Knaust \& R.G. Bromley (eds.) Developments in Sedimentology, 64:157-194. doi:10.1016/B978-0-444-538130.00006- $X$

Mahboubi, M.; Tabuce, R.; Mebrouk, F.; Coiffait, B.; Coiffait, P.E. \& Jaeger J.J. 2003. L'Eocène continental à vertébrés de la bordure sud des monts des Nementcha (Atlas saharien oriental, Algérie). Précisions stratigraphiques et implications paléobiogéographiques. Bulletin du Service Géologique de l'Algérie, 14:27-35.

Mángano, M.G. \& Buatois, L.A. 2003. Trace-fossils. In: J.L. Benedetto (ed.) Ordovician Fossils of Argentina, Universidad Nacional de Córdoba, Secretaría de Cienciay Tecnología, p. 507-553.

Mángano, M.G. \& Buatois, L.A. 2016. The trace-fossil record of major evolutionary events. Volume 2: Mesozoic and Cenozoic. Dordrecht, Springer, 485 p. doi:10.1007/978-94-017-9597-5

Mángano, M.G.; Buatois, L.A. \& Muniz-Guinea, F. 2005. Ichnology of the Alfarcito Member (Santa Rosita Formation) of northwestern Argentina: animal-substrate interactions in a lower Paleozoic wave-dominated shallow sea. Ameghiniana, 42:641-668.

Mángano, M.G.; Buatois, L.A.; West, R.R. \& Maples, C.G. 1999. The origin and paleoecologic significance of the tracefossil Astericites in the Pennsylvanian of Kansas and Missouri. Lethaia, 32:17-30. doi:10.1111/j.1502-3931.1999.tb00577.x

Mazouz, E.H. 2009. Étude sédimentologique, stratigraphique et pétro minéralogique des affleurements miocènes aux environs d'Aïn Sidi Salah et de Fedj El Behim (Ouenza-Confins algérotunisiens). Université de Tebessa, M.Sc. thesis, 89 p.

Melchor, R.N.; Genise, J.F.; Buatois, L.A. \& Umazano, A.M. 2012. Fluvial environments. In: D. Knaust \& R.G. Bromley (eds.) Trace-fossils as indicators of sedimentary environments, Elsevier, p. 329-378. doi:10.1016/B978-0-444-53813-0.00004-6

Monaco, P. \& Trecci T. 2014. Ichnocoenoses in the Macigno turbidite basin system, Lower Miocene, Trasimeno (Umbrian Apennines, Italy). Italian Journal of Geoscience, 133:116-130. doi:10.3301/ IJG.2013.18 
Myrow, P.M. 1995.Thalassinoides and the enigma of early Paleozoic open-framework burrow systems. Palaios, 10:58-74. doi:10.3301/IJG.2013.18

Naimi, M.N. 2019. La plate-forme carbonate messinienne du Djebel Aoud Sma (Monts des Ouled Ali, Bassin du Bas Chélif): sédimentologie et géochimie. University of Oran 2, M.Sc. thesis, $53 \mathrm{p}$.

Naimi, M.N. \& Cherif, A. 2021. Ichnological analysis of the late Miocene shallow marine diatomaceous deposits of the Lower Chelif basin (northwestern Algeria): paleoenvironmental insights and comparison with deep diatomites. Journal of African Earth Sciences, 180:104239. doi:10.1016/j.afrearsci.2021.104239

Naimi, M.N.; Cherif, A. \& Belaid, M. 2021b. The trace-fossil Cardioichnus planus from the lower Miocene of Algeria: the first record from Africa and a probable endemic tracemaker. Geologia Croatica, 74:121-126. doi:10.4154/gc.2021.09

Naimi, M.N.; Mansour, B. \& Cherif, A. 2020b. First record of the Halimeda-rich beds from the Tessala - Beni Chougrane Messinian carbonate platform (Lower Chelif basin, NW Algeria). In: GEOCONVENTION, 2020. Abstracts, Calgary, p. 1-5.

Naimi, M.N.; Mansour, B.; Cherif, A.; Chekkali, M.C.; Benkhedda, A. \& Belaid, M. 2020a. Lithostratigraphie et paléoenvironnements des dépôts messiniens du Djebel Aoud Sma (bassin du Bas Chélif, Algérie nord-occidentale). Revue de Paléobiologie, 39:467-483.

Naimi, M.N.; Vinn, O. \& Cherif, A. 2021a. Bioerosion in Ostrea lamellosa shells from the Messinian of the Tafna basin (NW Algeria). Carnets de Géologie, 21:127-135. doi:10.2110/ carnets.2021.2105

Narbonne, G.M. \& Aitken, J.D. 1990. Ediacaran fossils from the Sekwi Brook area Mackenzie Mountains, northwestern Canada. Palaeontology, 33:945- 980.

Narbonne, G.M. \& Hofmann, H.J. 1987. Ediacaran biota of the Wernecke Mountains, Yukon, Canada. Palaeontology, 30:647-676.

Netto, R.G.; Benner, J.S.; Buatois, L.A.; Uchman, A.; Mángano, M.G.; Ridge, J.C.; Kazakauskas, V. \& Gaigalas, A. 2012. Glacial Environments. In: D. Knaust \& R.G. Bromley (eds.) Tracefossils as Indicators of Sedimentary Environments, Elsevier, p. 299-327. doi:10.1016/B978-0-444-53813-0.00004-6

Nickel, L.A. \& Atkinson, R.J.A. 1995. Functional morphology of burrows and trophic modes of three thalassinidean shrimp species, and a new approach to the classification of thalassinidean burrow morphology. Marine Ecology Progress Series, 128:181197.

Palma-Ramírez, A.; Maldonado-Sarabia, R.C. \& Stimson, M.R. 2019. Marginal marine trace-fossils from the Cárdenas Formation (Maastrichtian), Rayón municipality, San Luis Potosí, central Mexico. Revista Brasileira de Paleontologia, 22:89-96. doi:10.4072/rbp.2019.2.01

Pemberton, S.G. \& Frey, R.W. 1982. Trace-fossil nomenclature and the Planolites-Palaeophycus dilemma. Journal of Paleontology, 56:843-881.

Pemberton, S.G.; Spila, M.; Pulham, A.J.; Saunders, T.; MacEachern, J.A.; Robbins, D. \& Sinclair, I.K. 2001. Ben Nevis \& Avalon Reservoirs, Jeanne d'Arc Basin. St. John's, Geological Association of Canada, Short Course Notes 15, $343 \mathrm{p}$. doi:10.1669/0883-1351(2003)018<0471: IASOST>2.0.CO;2

Pervesler, P. \& Uchman, A. 2004. Ichnofossils from the type area of the ground formation (Miocene, Lower Badenian) in Northern Lower Austria (Molasse Basin). Geologica Carpathica, 55:103-110.
Rodríguez-Tovar, F.J.; Alcalá, L. \& Cobos, A. 2016. Taenidium at the lower Barremian El Hoyo dinosaur tracksite (Teruel, Spain): assessing palaeoenvironmental conditions for the invertebrate community. Cretaceous Research, 65:48-58. doi:10.1016/j. cretres.2016.04.013

Ruault-Djerrab, M.; Kechid-Benkherouf, F. \& Djerrab, A. 2014. Données paléoenvironnementales sur le Vraconnien/ Cénomanien de la région de Tébessa (Atlas Saharien, nord-est Algérie). Caractérisation de l'OAE2. Annales de Paléontologie, 100:343-359. doi:10.1016/j.annpal.2014.03.002

Smilek, K.R. \& Hembree, D.I. 2012. Neoichnology of Thyonellagemmata: a case study for understanding holothurian ichnofossils. The Open Paleontology Journal, 4:1-10. doi:10.2174/1874425701204010001

Stanley, T.M. \& Feldmann, R.M. 1998. Significance of nearshore trace- fossil assemblages of the Cambro-Ordovician Deadwood Formation and Aladdin Sandstone, South Dakota. Annals of Carnegie Museum, 67:1-51.

Sundberg, F.A. 1983. Skolithos linearis Haldeman from the Carrara Formation (Cambrian) of California. Journal of Paleontology, 57:145-149.

Uchman, A. 1995. Taxonomy and palaeoecology of flysch tracefossils: the Marnoso-arenacea Formation and associated facies (Miocene, Northern Apennines, Italy). Beringeria, 15:3-115.

Uchman, A. 1998. Taxonomy and ethology of flysch trace-fossils: a revision of the Marian Książkiewicz collection and studies of complementary material. Annales Societatis Geologorum Poloniae, 68:105-218.

Uchman, A. \& Hanken, N.M. 2013. The New Trace-fossil Gyrolitheslorcaensis isp. n. from the Miocene of SE Spain and a Critical Review of the Gyrolithes Ichnospecies. Stratigraphy and Geological Correlation, 21:312-322. doi:10.1134/ S0869593813030088

Vinn, O. \& Wilson, M.A. 2013. An event bed with abundant Skolithos burrows from the late Pridoli (Silurian) of Saaremaa (Estonia). Carnets de Géologie, 13:83-87.

Wetzel, A.; Blechschmidt, I.; Uchman, A. \& Matter, A. 2007. A highly diverse ichnofauna in Late Triassic deep-sea fan deposits of Oman. Palaios, 22:567-576. doi:10.2110/palo. 2006.p06-98r

Wetzel, A. \& Bromley, R.G. 1996. Re-evaluation of the ichnogenus Helminthopsis-a new look at the type material. Palaeontology, 39:1-19.

Wilson, E.O. 1971. The insect societies. Cambridge, Belknap Press, $548 \mathrm{p}$.

Wilson, M.A. \& Rigby, J.K. 2000. Asteriacites lumbricalis von Schlotheim 1820: ophiuroid trace-fossils from the Lower Triassic Thaynes Formation, central Utah. Ichnos, 7:43-49. doi: 10.1080/10420940009380145

Yochelson, E.L. \& Fedonkin, M.A. 1997. The type specimens (Middle Cambrian) of the trace-fossil Archaeonassa Fenton \& Fenton. Canadian Journal of Earth Sciences, 34:1210-1219. doi:10.1139/e17-097

Yuanyuan, W.; Xueqin, W.; Uchman, A.; Bin, H. \& Huibo, S. 2019. Burrows of the polychaete Perinereis aibuhiutensis on a tidal flat of the yellow river delta in China: implications for the ichnofossils Polykladichnus and Archaeonassa. Palaios, 34:271-279. doi:10.2110/palo.2018.105

Received in 01 January, 2021; accepted in 02 June, 2021. 